\section{$\underset{\text { hommes }}{\text { \& migrations }}$}

\section{Hommes \& migrations}

Revue française de référence sur les dynamiques

migratoires

1286-1287 | 2010

Les migrations subsahariennes

\title{
Les Murmures du vent
}

Film Kudrdo-irakien de Shahram Alidi

\section{André Videau}

\section{OpenEdition \\ 1 Journals}

\section{Édition électronique}

URL : http://journals.openedition.org/hommesmigrations/1676

DOI : 10.4000/hommesmigrations. 1676

ISSN : 2262-3353

\section{Éditeur}

Musée national de l'histoire de l'immigration

\section{Édition imprimée}

Date de publication : 1 juillet 2010

Pagination : 302

ISSN : 1142-852X

\section{Référence électronique}

André Videau, « Les Murmures du vent », Hommes \& migrations [En ligne], 1286-1287| 2010, mis en ligne le 29 mai 2013, consulté le 22 septembre 2020. URL : http://journals.openedition.org/ hommesmigrations/1676; DOI : https://doi.org/10.4000/hommesmigrations.1676

Ce document a été généré automatiquement le 22 septembre 2020.

Tous droits réservés 


\title{
Les Murmures du vent
}

\author{
Film Kudrdo-irakien de Shahram Alidi
}

\section{André Videau}

Il aura fallu à Shahram Alidi quatre années de patients efforts pour réaliser son premier long-métrage: Les Murmures du vent - Wisper with the Wind - (Sirta la gal ba). Né à Sanandja, au Kurdistan iranien, dans cette zone âprement disputée entre l'Iran, l'Irak et les revendications irrédentistes des tribus et territoires kurdes, l'auteur ne pouvait que se faire l'écho, ou le porte-voix des populations soumises à tant d'incertitudes géopolitiques. Pour ce faire, il n'a pas choisi l'exposé documentaire, difficilement séparable, dans un contexte historique précis et polémique (les souffrances des habitants "apatrides" réduits au nomadisme du fait de "l'Anfal", la politique d'extermination menée à leur encontre par les troupes de Saddam Hussein) d'un réquisitoire univoque. Faisant référence à l'épopée mésopotamienne de Gilgamesh et à ses mythes fondateurs, il a opté pour une sorte de road-movie lyrique où les thèmes réalistes sont entremêlés aux symboles, les sons portés par les images dans la complexité d'un film à la fois tableau, poème et symphonie. S'il n'était poussé par le souffle de l'histoire, le fil de l'intrigue serait mince. Mam Baldar "l'oncle aux ailes" n'est pas un postier ordinaire. Colporteur de nouvelles en temps de paix, il parcourt les villages isolés au volant de sa camionnette. Quand la situation s'envenime, avec magnétophone et transistor, il devient envoyé spécial, agent double, facteur de trouble ou d'espoir. C'est ainsi qu'un jour, éloigné des siens sur le front des partisans, un chef de section lui demande d'aller enregistrer le premier cri de son fils et de le transmettre sur les ondes des radios clandestines, captables jusque dans les hameaux les plus reculés. Pour accomplir sa mission, Mam Baldar traverse un pays où alternent tombeaux et arbres de vie, danses païennes et célébrations de mariage, les lamentations des exilés et le chant du rossignol du Kurdistan en tête du hit-parade, la désolation ou la splendeur des paysages, les souvenirs de l'enfance et les traces des carnages...

On peut trouver parfois excessif ce lyrisme qui sublime la réalité, même s'il atténue par la précarité des conditions de tournage (en lumière naturelle et en se réglant sur les saisons ) et par le jeu rude des acteurs non professionnels. Néanmoins les prix et les festivals en raffolent et Les Murmures du vent sont promis à un important palmarès. 
Shahram Alidi devrait y trouver les encouragements et les moyens de poursuivre son œuvre. 